\title{
Treatment Protocol for Controlling Bone Metabolism Parameters in Hemodialysis Patients
}

\author{
Pablo Molina, Pilar Sánchez-Pérez, Ana Peris, \\ José L. Górriz and Luis M. Pallardó \\ Department of Nephrology, Hospital Universitario Dr Peset $\mathcal{E}$ \\ Division of Nephrology, Hospital Francesc de Borja, Valencia \\ Spain
}

\section{Introduction}

Abnormal mineral metabolism and severe secondary hyperparathyroidism play a key role in the pathophysiology of skeletal and extraskeletal calcification and are associated with increased morbidity and mortality among hemodialysis (HD) patients (Block GA et al., 1998, 2004; Ganesh et al., 2001; London GM et al., 2003). As a result of these findings, the National Kidney Foundation introduced guidelines in 2003 on controlling parathyroid hormone $(\mathrm{PTH})$, calcium $(\mathrm{Ca})$, phosphorous $(\mathrm{P})$ and calcium-phosphorous ion product $(\mathrm{CaxP})$ in these patients (National Kidney Foundation-Kidney Disease Outcomes and Quality Initiative, 2003). However, in spite of the publication of the K/DOQI guidelines, most HD patients remained outside the recommended targets (Al Aly et al., 2004; Arenas et al., 2006; Lorenzo et al., 2006; Maduell et al., 2005). Historically, Ca-containing phosphate binders and vitamin D have provided the main strategies for reducing P and PTH levels (Slatopolsky et al., 1986). However, the overuse of Ca-containing phosphate binders and active vitamin $\mathrm{D}$ can result in hypercalcemia, high CaxP level and Ca overload, which may accelerate vascular disease and hasten death. These side effects potentially require temporary cessation of vitamin $\mathrm{D}$ and a reduction in Ca-containing binder administration. This cycle results in a temporary worsening of secondary hyperparathyroidism, allowing bone disease progression (Block et al., 1998, 2000; Johnson et al., 2002; Moe et al., 2003). Hence, new treatment strategies are required (Jindal et al., 2006; Moe et al., 2009;).

Since 2006, two new drugs, paricalcitol and cinacalcet, have been available in daily clinical practice for secondary hyperparathyroidism treatment. Paricalcitol is a vitamin D metabolite that has some advantages over calcitriol, the standard form of vitamin D used worldwide. Paricalcitol suppresses PTH faster than calcitriol (Sprague et al., 2001), and may have a lesser $\mathrm{Ca}$ and $\mathrm{P}$ intestinal absorption capacity, with smaller increases in Ca and P serum (Llach et al., 2001). Patients who receive paricalcitol may also have a significant survival advantage over those who receive calcitriol (Teng et al., 2003). Despite these advantages, the occurrence of hypercalcemia and high CaxP, when high doses of paricalcitol are used, is not unusual (Goodman, 2001; Martin \& Gonzalez, 2001). 
Cinacalcet, the first calcimimetic available, has provided a new approach for severe secondary hyperparathyroidism. It increases the sensitivity of the Ca-sensing receptor on the parathyroid cell surface to extracellular Ca ions, thereby inhibiting the release of PTH. All clinical trials concluded that cinacalcet is effective in reducing PTH while simultaneously lowering Ca, P and CaxP levels in HD patients (Block et al, 2004; Goodman et al., 2002; Lindberg et al., 2005; Quarles et al., 2003). All these effects could facilitate achievement of the K/DOQI recommended targets (Block et al., 2008; Messa et al, 2008; Moe et al., 2005).

Given the difficulty of achieving K/DOQI targets, and the absence of treatment algorithms that take into account both drug treatment (conventional drugs like phosphate binders, and new drugs like paricalcitol and cinacalcet) and HD features, such as the length of dialysis session or the dialysate Ca concentration recommended, our HD Unit has, since 2006, implemented a new treatment protocol for controlling bone metabolism parameters. The aim of our study was to evaluate the long-term effect of applying this protocol on achieving K/DOQI targets.

\section{Materials and methods}

\subsection{Study design}

This is a single-centre, intervention study. HD patients were eligible for inclusion if they were adults (age $\geq 18$ years) and if they had attended our HD unit for at least 3 months from Jan 2006 to April 2008. Patients who had been on HD therapy for less than 3 months, or who presented excessively suppressed parathyroid hormone (PTH $<10 \mathrm{pg} / \mathrm{mL}$ ) secondary to previous parathyroidectomy, were excluded. Starting in April 2006, the new protocol treatment was applied to 52 of the 57 patients attending our unit over this two year period. Five patients were excluded (in every case because of a stay in our HD unit of less than 3 months).

\subsection{Interventions}

This intervention study consisted of three stages: an assessment stage 3 months before applying the protocol (base period), and the 12 and 24 month effectiveness assessment phases. During the base period (January-March 2006), calcitriol was the only drug available for hyperparathyroidism treatment, and a bath containing $2.5 \mathrm{mEq} / \mathrm{L}$ of $\mathrm{Ca}$ was preferentially used, as K/DOQI guidelines recommended. Since April 2006, treatment for control bone metabolism parameters, including cinacalcet administration, has been adjusted according to our new protocol. All patients treated with calcitriol, were changed to paricalcitol. Dialysate Ca content was determined individually, based on the protocol. In all three stages, Ca acetate was the only Ca-containing phosphate binder used, in order to limit the total dosage of elemental Ca provided. The preferred non-Ca phosphate binder used was sevelamer, up to a maximum dose of $4800 \mathrm{mg}$ per day. Only if $\mathrm{P}$ remained $>5.5 \mathrm{mg} / \mathrm{dL}$, in spite of full doses of $\mathrm{Ca}$ acetate and sevelamer, was treatment with aluminium hydroxide considered. In line with K-DOQI guidelines, we tried to maintain serum Ca levels within the normal range for our laboratory $(8.4-10.2 \mathrm{mg} / \mathrm{dL})$, and preferably towards the lower end (8.4-9.5 mg/dL); P below $5.5 \mathrm{mg} / \mathrm{dL}$; CaxP below $55 \mathrm{mg}^{2} / \mathrm{dL}^{2}$; and PTH levels between 150 and $300 \mathrm{pg} / \mathrm{mL}$. The protocol consisted in three treatment algorithms, depending on the PTH level. When parathyroid hormone level was less than $150 \mathrm{pg} / \mathrm{mL}$ (Figure 1), depending on Ca levels, the dose of cinacalcet or paricalcitol was reduced gradually, until a minimum dose (oral cinacalcet, $30 \mathrm{mg}$ three times per week; intravenous paricalcitol, $2.5 \mu \mathrm{g}$ once per 
When parathyroid hormone was over $300 \mathrm{pg} / \mathrm{mL}$ (Figure 3), and Ca $<9.5 \mathrm{mg} / \mathrm{dL}$, dialysate Ca concentration were raised from 2.5 to $3.0 \mathrm{mEq} / \mathrm{L}$, and we increased paricalcitol or cinacalcet, depending on whether the $\mathrm{P}$ and CaxP levels were normal or too high, respectively. Increases in the length of dialysis session and in the Ca acetate dosage were also considered. When Ca levels were between 9.5 to $10.2 \mathrm{mg} / \mathrm{dL}$ and CaxP $<55 \mathrm{mg}^{2} / \mathrm{dL}^{2}$, cinacalcet was preferentially used. If PTH remained too high, in spite of full doses of cinacalcet, we considered changing $\mathrm{Ca}$ acetate to sevelamer and increasing dialysate $\mathrm{Ca}$ concentration or adding low doses of paricalcitol, carefully monitoring CaxP levels. When Ca levels were too high or within the high-normal range and $\mathrm{CaxP}>55 \mathrm{mg}^{2} / \mathrm{dL}^{2}$, paricalcitol was reduced or withdrawn and the cinacalcet dosage was increased. We also considered increasing the length or frequency of dialysis session and the dosage of non-Ca phosphate binders, and reducing the dialysate Ca concentration.

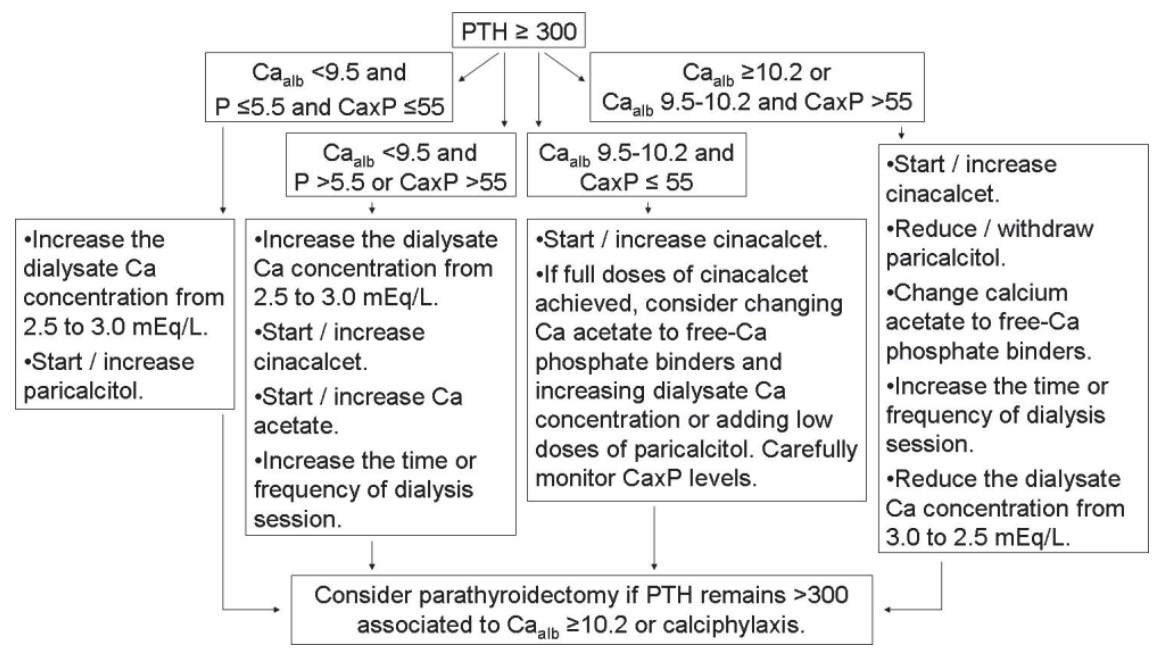

Fig. 3. Algorithm treatment when parathyroid hormone was over 300 pg/mL.

\subsection{Laboratory tests}

All blood samples were collected at the start of the dialysis session following the longest interdialysis period. The samples were analyzed for serum $\mathrm{Ca}, \mathrm{P}$ and intact PTH. All KDOQI parameters were measured at least monthly. In total, 863 blood samples were analyzed (median: 16.9 samples per patient). Total serum $\mathrm{Ca}$ and $\mathrm{P}$ were measured by colorimetric assay (Roche Diagnostics $\mathrm{GmbH}$, Mannheim, Germany), the reference value for serum calcium being $8.6-10.4 \mathrm{mg} / \mathrm{dL}$ and for phosphate $3.5-5.5 \mathrm{mg} / \mathrm{dL}$. The serum levels of total $\mathrm{Ca}$ were adjusted for circulating albumin levels (reference values: $3.4-4.8 \mathrm{~g} / \mathrm{dL}$ ). Albumin levels were assessed by Albumin BCG Method (Roche Diagnostics GmbH, Mannheim, Germany). PTH levels were assessed by an electrochemiluminescence immunoassay (Elecsys, Roche Diagnostics $\mathrm{GmbH}$, Mannheim, Germany). The reference range for healthy adults is $15-65 \mathrm{pg} / \mathrm{mL}$.

\subsection{Renal replacement therapy}

Patients received standard HD or post-dilution hemodiafiltration (HDF) treatment, lasting between $3 \mathrm{~h}$ and $4 \mathrm{~h} 30 \mathrm{~m}$, three times per week.Dialysis prescription was monitored to 
maintain Kt/V>1.2- Polysulphone or AN69st membrane dialysers were used. Blood flow was at least $300 \mathrm{~mL} / \mathrm{min}$ and dialysate flow $750 \mathrm{~mL} / \mathrm{min}$. Dialysate composition was Ca 2.5 or 3.0, Na 139 or $140, \mathrm{~K} 1.5$ or 1.9 , bicarbonate 34,37 or $40.8, \mathrm{mEq} / \mathrm{L}$. Infusate composition for patients on HDF was $\mathrm{Na} 145, \mathrm{Cl} 85$, bicarbonate $60 \mathrm{mmol} / \mathrm{L}$, with an infusion flow of 2 L/hour. The dialysis equipment employed was Bellco ${ }^{\circledR}$ or Hospal ${ }^{\circledR}$.

\subsection{Statistics}

Student's unpaired $t$-test was used to compare the three phase means of all PTH, Ca, P and CaxP values. The proportion of patients within K/DOQI target ranges over the 2 years following the implemention of the protocol was used to evaluate effectiveness. Percentages were compared using the chi-square test. We analyzed potential factors involved in the evolution of bone metabolism parameters, such as phosphate binder dosage, the cinacalcet and paricalcitol used, and the features of HD employed. Results are expressed as mean and standard deviation. A multivariate analysis of the factors associated with the achievement of all four K/DOQI target ranges during the last year were assessed using logistic regression analysis. A value of $p<0.05$ was considered statistically significant.

\section{Results}

\subsection{Patients}

Fifty-two patients were studied, twenty-nine men and twenty-three women, $66.7 \pm 17.7$ years old (range, 25 to 86 years) with a mean time on HD therapy of $71 \pm 84$ months (range, 4 to 318 months). The etiology of renal failure was hypertensive nephrosclerosis $(n=12)$, diabetic nephropathy $(n=10)$, glomerulonephritis $(n=9)$, interstitial nephritis $(n=8)$, polycystic kidney disease $(n=2)$, Alport's syndrome $(n=1)$, and undetermined $(n=10)$. The demographics of the patients studied at each stage of the study are summarized in Table 1. Mean observation time was $16.7 \pm 9.4$ months.

\begin{tabular}{|l|c|c|c|}
\hline & Baseline & 1 year & 2 years \\
\hline Number of patients dialysed & 30 & 36 & 43 \\
\hline Number of prevalent patients & 25 & 28 & 30 \\
\hline Number of incident patients & 5 & 8 & 13 \\
\hline \multirow{2}{*}{ Mean age of patients (years) } & $\begin{array}{c}67.7 \pm 16.9 \\
(25-84)\end{array}$ & $\begin{array}{c}67.2 \pm 17.3 \\
(25-85)\end{array}$ & $\begin{array}{c}66.6 \pm 16.4 \\
(31-86)\end{array}$ \\
\hline \multirow{2}{*}{ Mean time on HD (months) } & $113 \pm 89$ & $94 \pm 89$ & $70 \pm 86$ \\
& $(12-294)$ & $(6-306)$ & $(3-318)$ \\
\hline \multirow{2}{*}{ Mean serum albumin (g/dL) } & $3.8 \pm 0.3$ & $3.8 \pm 0.3$ & $3.7 \pm 0.4$ \\
& $(3.5-4.6)$ & $(2.8-4.6)$ & $(2.5-4.6)$ \\
\hline$\%$ of diabetic patients & $20 \%(6)$ & $17 \%(6)$ & $26 \%(11)$ \\
\hline
\end{tabular}

Table 1. Demographic characteristics of patient population at each stage of the study.

\subsection{Evolution of biochemical parameters}

Changes in the adjusted $\mathrm{Ca}\left(\mathrm{Ca}_{\mathrm{Alb}}\right), \mathrm{P}, \mathrm{CaxP}$, and $\mathrm{PTH}$ levels before and after implementing the protocol are shown in Table 2. $\mathrm{Ca}_{\mathrm{Alb}}$, CaxP and PTH levels decreased significantly throughout the study, with a mean decrease of $3.5 \%(p=0.016), 8.2 \%(p=0.023)$ and $39.4 \%$ $(p=0.002)$, respectively. Although there was a reduction in P levels, the difference did not reach statistical significance $(p=0.075)$. 


\begin{tabular}{|c|c|c|c|c|}
\hline & Baseline & 1 year & 2 years & $p$ \\
\hline $\mathrm{Ca}_{\mathrm{Alb}}(\mathrm{mg} / \mathrm{dL})$ & $\begin{array}{c}9.46 \pm 0.57 \\
(8.26-10.45)\end{array}$ & $\begin{array}{c}9.20 \pm 0.529 \\
(7.54-10.24)\end{array}$ & $\begin{array}{c}9.13 \pm 0.56 \\
(7.35-10.40)\end{array}$ & 0.016 \\
\hline $\mathrm{P}(\mathrm{mg} / \mathrm{dL})$ & $\begin{array}{c}4.97 \pm 1.09 \\
(3.29-7.91)\end{array}$ & $\begin{array}{c}4.62 \pm 0.94 \\
(3.02-6.7)\end{array}$ & $\begin{array}{c}4.56 \pm 0.84 \\
(3.05-6.79)\end{array}$ & 0.075 \\
\hline $\mathrm{CaxP}\left(\mathrm{mg}^{2} / \mathrm{dL}^{2}\right)$ & $\begin{array}{c}47.36 \pm 11.33 \\
(29.97-79.81)\end{array}$ & $\begin{array}{c}42.58 \pm 9.03 \\
(27.10-63.26)\end{array}$ & $\begin{array}{c}41.65 \pm 8.27 \\
(26.91-65.52)\end{array}$ & 0.023 \\
\hline $\mathrm{PTH}(\mathrm{pg} / \mathrm{mL})$ & $\begin{array}{c}343 \pm 209 \\
(11-864)\end{array}$ & $\begin{array}{c}239 \pm 126 \\
(36-678)\end{array}$ & $\begin{array}{c}208 \pm 107 \\
(42-704)\end{array}$ & 0.002 \\
\hline
\end{tabular}

Table 2. Evolution of Biochemical Parameters.

Mean corrected calcium, serum phosphorus, ion calcium-phosphorus product, and intact parathyroid hormone levels at each stage of the study were compared using Student's unpaired $t$-test.

\subsection{Achievement of K/DOQI target levels}

The percentages of patients achieving the K/DOQI targets are summarized in Figure 4 . In the base period, the proportion of patients achieving P, CaxP and PTH targets were $67 \%$, $73 \%$ and $13 \%$ respectively. An improvement in the achievement of these three targets was observed, reaching $84 \%, 93 \%$ and $72 \%$ of patients, respectively. This improvement was significant in CaxP and PTH levels ( $p=0.024$ and $p<0.001$, respectively). The increase in the percentage of patients achieving $P$ target did not reach statistical significance $(p=0.074)$. The proportion of patients achieving $\mathrm{Ca}_{\mathrm{Alb}}$ levels remained above $90 \%$ throughout the study $(p=0.644)$. Overall, the rate of patients with all four K-DOQI parameters within target ranges improved significantly from 10.0 at baseline, to $33.3 \%(p=0.023)$ and to $60.5 \%(p<0.001)$ during the first and second year after implementing the protocol, respectively (Figure 5).

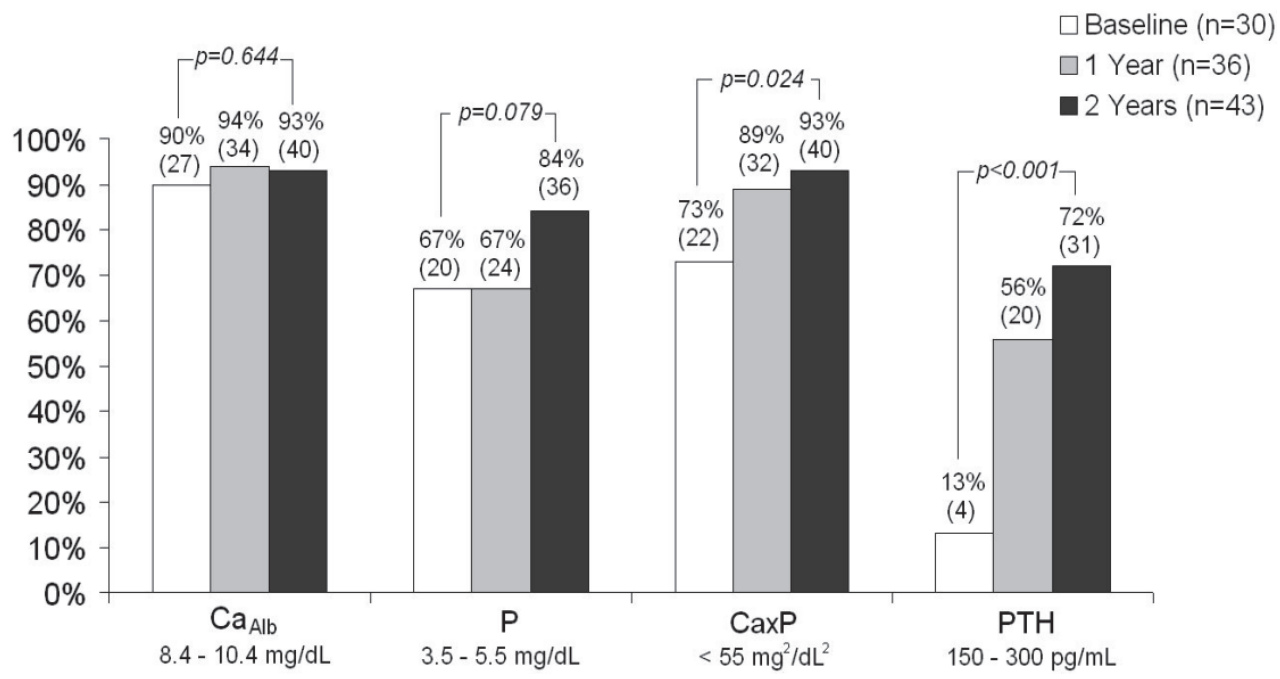

Fig. 4. Percentage (\%) of patients achieving each K/DOQI target by time period. 


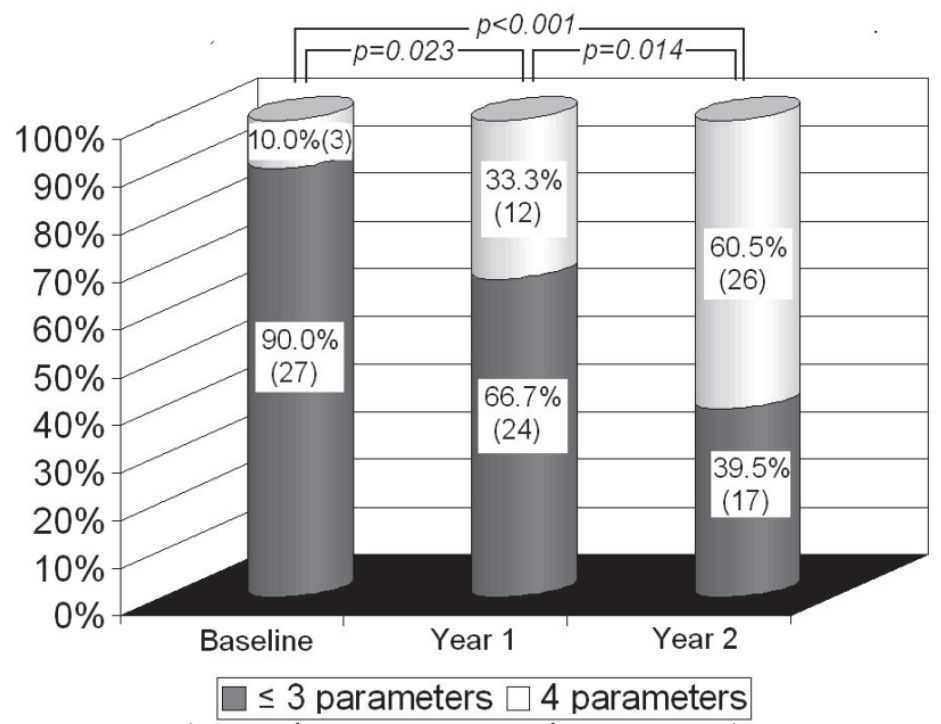

Fig. 5. Percentage (\%) of patients achieving all four K/DOQI targets by time period.

\subsection{Medication use}

Treatment of osteodystrophy over time is shown in Table 3. As the protocol stated, all patients treated with calcitriol were changed to paricalcitol, which was administered to approximately a third of the patients throughout the study. Cinacalcet was the other drug available for HPT, and was administered to $22 \%$ and $26 \%$ of patients during the first and second year after implementing the protocol, respectively. Two drugs were administered in combination to $5(12 \%)$ and $6(14 \%)$ patients in each assessment stage. Ca acetate was the only calcium-based phosphate binder used, and the proportion of patients receiving this drug remained unchanged (70\% of patients, approximately). The mean total dosage of elemental calcium provided by calcium acetate increased from $451 \pm 151$ to $562 \pm 275 \mathrm{mg}$ / day without statistical significance $(p=0.079)$. The proportion of patients under treatment with aluminium hydroxide at the start of the study was significantly reduced from $20 \%(n=6)$ to $5 \%(n=2)(p=0.047)$. Its dose remained unchanged throughout the study.

Mean total dosage of calcium acetate is expressed as elemental calcium provided by calcium acetate. Mean doses were compared using Student's unpaired $t$-test. Percentages were compared using the chi-square test. Abbreviations: n: number of patients; n.a.: not applicable. †Mean dose of aluminium hydroxide cannot be computed because the standard deviations of both groups were 0 .

\subsection{Renal replacement therapy}

Changes in HD features over time are shown in Table 4. After implementing the protocol, a $3.0 \mathrm{mEq} / \mathrm{L}$ dialysate Ca concentration became the most widely used ( $\%$ vs. $72 \% ; \mathrm{p}=0.001)$, and a significant increase in the proportion of patients under convective therapy was detected ( $30 \%$ vs. $67 \%$; $p=0.034)$. The length of dialysis session and the HD dose remained unchanged. 


\begin{tabular}{|c|c|c|c|c|}
\hline & $\begin{array}{c}\text { Baseline } \\
(\mathrm{n}=30)\end{array}$ & $\begin{array}{l}1 \text { year } \\
(\mathrm{n}=36)\end{array}$ & $\begin{array}{l}2 \text { years } \\
(n=43)\end{array}$ & $p$ \\
\hline $\begin{array}{l}\text { Rocaltrol } \\
\mathrm{n},(\%) \text { patients on treatment } \\
\text { mean dose }(\mu \mathrm{g} / \text { week })\end{array}$ & $\begin{array}{c}13(43 \%) \\
1.44 \pm 0.21 \\
(0.75-1.50) \\
\end{array}$ & 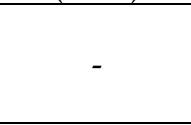 & 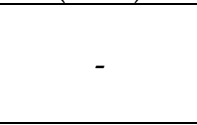 & $\begin{array}{l}\text { n.a. } \\
\text { n.a. }\end{array}$ \\
\hline $\begin{array}{l}\text { Paricalcitol } \\
\mathrm{n},(\%) \text { patients on treatment } \\
\text { mean dose }(\mu \mathrm{g} / \text { week })\end{array}$ & - & $\begin{array}{c}16(44 \%) \\
9.93 \pm 5.19 \\
(2.50-22.50) \\
\end{array}$ & $\begin{array}{c}14(33 \%) \\
9.38 \pm 4.87 \\
(5.00-20.00) \\
\end{array}$ & $\begin{array}{l}\text { n.a. } \\
\text { n.a. }\end{array}$ \\
\hline $\begin{array}{l}\text { Cinacalcet } \\
\mathrm{n},(\%) \text { patients on treatment } \\
\text { mean dose }(\mathrm{mg} / \text { day })\end{array}$ & - & $\begin{array}{c}8(22 \%) \\
35.7 \pm 17.8 \\
(15-60) \\
\end{array}$ & $\begin{array}{c}11(26 \%) \\
45.0 \pm 34.6 \\
(15-120) \\
\end{array}$ & $\begin{array}{l}\text { n.a. } \\
\text { n.a. }\end{array}$ \\
\hline $\begin{array}{l}\text { Calcium acetate } \\
\mathrm{n},(\%) \text { patients on treatment } \\
\text { mean dose }(\mathrm{mg} / \text { day })\end{array}$ & $\begin{array}{c}20(67 \%) \\
451 \pm 151 \\
(254-762) \\
\end{array}$ & $\begin{array}{c}28(78 \%) \\
553 \pm 242 \\
(127-1143) \\
\end{array}$ & $\begin{array}{c}28(65 \%) \\
562 \pm 275 \\
(127-1143) \\
\end{array}$ & $\begin{array}{l}0.547 \\
0.079\end{array}$ \\
\hline $\begin{array}{l}\text { Sevelamer } \\
\mathrm{n},(\%) \text { patients on treatment } \\
\text { mean dose }(\mathrm{mg} / \text { day })\end{array}$ & $\begin{array}{c}20(67 \%) \\
4760 \pm 1916 \\
(2400-7200) \\
\end{array}$ & $\begin{array}{c}22(61 \%) \\
4255 \pm 1645 \\
(2400-7200) \\
\end{array}$ & $\begin{array}{c}26(61 \%) \\
4062 \pm 1662 \\
(800-7200) \\
\end{array}$ & $\begin{array}{l}0.386 \\
0.179\end{array}$ \\
\hline $\begin{array}{l}\text { Aluminium hydroxide } \\
\mathrm{n},(\%) \text { patients on treatment } \\
\text { mean dose }(\mathrm{mg} / \text { day })\end{array}$ & $\begin{array}{c}6(20 \%) \\
699 \pm 0 \\
(699-699) \\
\end{array}$ & $\begin{array}{c}2(6 \%) \\
699 \pm 0 \\
(699-699) \\
\end{array}$ & $\begin{array}{c}2(5 \%) \\
699 \pm 0 \\
(699-699) \\
\end{array}$ & $\begin{array}{c}0.047 \\
\dagger\end{array}$ \\
\hline
\end{tabular}

Table 3. Treatment of osteodystrophy at each stage of the study.

\begin{tabular}{|l|c|c|c|c|}
\hline & Baseline (n=30) & $\begin{array}{c}1 \text { year } \\
(\mathrm{n}=36)\end{array}$ & $\begin{array}{c}2 \text { years } \\
(\mathrm{n}=43)\end{array}$ & $p$ \\
\hline $\begin{array}{l}\text { Dialysate Ca concentration, } \mathrm{n}(\%) \\
\text { Patients with Ca 2.5 }\end{array}$ & $\begin{array}{c}28(93 \%) \\
2(7 \%)\end{array}$ & $\begin{array}{c}6(17 \%) \\
30(83 \%)\end{array}$ & $\begin{array}{c}12(28 \%) \\
31(72 \%)\end{array}$ & 0.001 \\
Patients with Ca 3.0 & $21(70 \%)$ & $\begin{array}{c}11(31 \%) \\
26(69 \%)\end{array}$ & $\begin{array}{c}14(33 \%) \\
29(67 \%)\end{array}$ & 0.034 \\
\hline $\begin{array}{l}\text { Dialysis type, } \mathrm{n}(\%) \\
\text { Hemodialysis }\end{array}$ & $\begin{array}{c}11.2 \pm 1.3 \\
\text { Hemodiafiltration }\end{array}$ & $\begin{array}{c}11.4 \pm 1.3 \\
(9.0-13.5)\end{array}$ & $\begin{array}{c}11.6 \pm 1.3 \\
(9.0-13.5)\end{array}$ & 0.481 \\
\hline $\begin{array}{l}\text { Length of dialysis session } \\
\text { (hours/week) }\end{array}$ & $\begin{array}{c}1.39 \pm 0.24 \\
(0.90-1.84)\end{array}$ & $\begin{array}{c}1.50 \pm 0.20 \\
(1.10-1.91)\end{array}$ & $\begin{array}{c}1.42 \pm 0.22 \\
(1.01-1.90)\end{array}$ & 0.439 \\
\hline Kt/V & & & & \\
\hline
\end{tabular}

Table 4. HD features at each stage of the study.

Student's unpaired $t$-test was used to compare means of length of dialysis session and Kt/V values. Percentages were compared using the chi-square test. Abbreviations: n: number of patients; URR: urea reduction ratio.

\subsection{Factors associated with achieving K/DOQI targets}

Data on each group of patients within and outside all four K/DOQI target ranges during the last year were compared (Table 5). The use of cinacalcet ( $39 \%$ vs. $6 \% ; p=0.017$ ) and the use of a $3.0 \mathrm{mEq} / \mathrm{L}$ dialysate Ca concentration $(85 \%$ vs. $53 \%$; $\mathrm{p}=0.028)$ were significantly more frequent in the group of patients who achieved all K/DOQI targets than in the group 


\begin{tabular}{|c|c|c|c|}
\hline & $\begin{array}{c}\leq 3 \mathrm{~K} / \text { DOQI targets } \\
\text { achieved }(\mathrm{n}=17)\end{array}$ & $\begin{array}{c}\text { All } 4 \text { K/DOQI targets } \\
\text { achieved }(n=26)\end{array}$ & $p$ \\
\hline Gender, n (\%) & & & \multirow{3}{*}{0.267} \\
\hline Female & $9(53 \%)$ & $10(39 \%)$ & \\
\hline Male & $8(47 \%)$ & $16(61 \%)$ & \\
\hline Age (years) & $67.98 \pm 15.88$ & $65.62 \pm 17.03$ & 0.650 \\
\hline Mean time on HD (months) & $50.21 \pm 55.56$ & $82.17 \pm 100.22$ & 0.756 \\
\hline Diabetes mellitus, n (\%) & $6(35 \%)$ & $5(19 \%)$ & 0.493 \\
\hline Mean serum albumin (g/dL) & $3.69 \pm 0.41$ & $3.76 \pm 0.36$ & 0.575 \\
\hline Mean $25 \mathrm{OH}$ vit $\mathrm{D}(\mathrm{ng} / \mathrm{mL})$ & $11.9 \pm 4.5$ & $12.4 \pm 4.5$ & 0.770 \\
\hline $\begin{array}{l}\text { Dialysate Ca concentration, } \mathrm{n} \\
(\%) \\
\text { Patients with Ca } 2.5 \\
\text { Patients with Ca } 3.0\end{array}$ & $\begin{array}{l}8(47 \%) \\
9(53 \%)\end{array}$ & $\begin{array}{c}4(15 \%) \\
22(85 \%)\end{array}$ & 0.028 \\
\hline Dialysis type, $\mathrm{n}(\%)$ & & & \multirow{3}{*}{0.259} \\
\hline Hemodialysis & $7(41 \%)$ & $7(27 \%)$ & \\
\hline Hemodiafiltration & $10(59 \%)$ & $19(73 \%)$ & \\
\hline $\begin{array}{l}\text { Length of dialysis session } \\
\text { (hours/ week) }\end{array}$ & $11.4 \pm 1.4$ & $11.5 \pm 1.2$ & 0.434 \\
\hline $\mathrm{Kt} / \mathrm{V}$ & $1.37 \pm 0.22$ & $1.46 \pm 0.21$ & 0.178 \\
\hline Residual diuresist, n (\%) & $3(18 \%)$ & $7(27 \%)$ & 0.375 \\
\hline $\begin{array}{l}\text { Paricalcitol } \\
\mathrm{n},(\%) \text { patients on treatment } \\
\text { mean dose }(\mu \mathrm{g} / \text { week })\end{array}$ & $\begin{array}{c}4(24 \%) \\
8.13 \pm 4.73 \\
\end{array}$ & $\begin{array}{c}10(39 \%) \\
9.79 \pm 5.05 \\
\end{array}$ & $\begin{array}{l}0.247 \\
0.573 \\
\end{array}$ \\
\hline $\begin{array}{l}\text { Cinacalcet } \\
\mathrm{n},(\%) \text { patients on treatment } \\
\text { mean dose }(\mathrm{mg} / \text { day })\end{array}$ & $\begin{array}{c}1(6 \%) \\
30 \\
\end{array}$ & $\begin{array}{c}10(39 \%) \\
46.7 \pm 36.6 \\
\end{array}$ & $\begin{array}{l}0.017 \\
0.909 \\
\end{array}$ \\
\hline $\begin{array}{l}\text { Calcium acetate } \\
\mathrm{n},(\%) \text { patients on treatment } \\
\text { mean dose }(\mathrm{mg} / \text { day })\end{array}$ & $\begin{array}{l}11(65 \%) \\
577 \pm 323\end{array}$ & $\begin{array}{l}17(65 \%) \\
553 \pm 250\end{array}$ & $\begin{array}{l}0.608 \\
0.434 \\
\end{array}$ \\
\hline $\begin{array}{l}\text { Sevelamer } \\
\mathrm{n},(\%) \text { patients on treatment } \\
\text { mean dose }(\mathrm{mg} / \text { day })\end{array}$ & $\begin{array}{c}10(39 \%) \\
4000 \pm 1131\end{array}$ & $\begin{array}{c}16(62 \%) \\
4100 \pm 1957\end{array}$ & $\begin{array}{l}0.554 \\
0.870\end{array}$ \\
\hline $\begin{array}{l}\text { Aluminium hydroxide } \\
\mathrm{n},(\%) \text { patients on treatment }\end{array}$ & $2(12 \%)$ & $0(0 \%)$ & 0.151 \\
\hline
\end{tabular}

Table 5. Characteristics of the patients who achieved all K/DOQI target ranges during the second year period and those who did not. Mean total dosage of calcium acetate is expressed as elemental calcium provided by calcium acetate. Student's unpaired $t$-test was used to compare means. Percentages were compared using the chi-square test. Abbreviation: $n$, number of patients; $25 \mathrm{OH}$ vit $\mathrm{D}, 25-$ Hydroxyvitamin $\mathrm{D}$; URR, urea reduction ratio. † Residual diuresis is defined as diuresis $>1000 \mathrm{~mL} / 24 \mathrm{~h}$ and residual $\mathrm{KtV}$ $\geq 0.4$. 
outside ranges. Although there was a higher proportion of patients under paricalcitol treatment (39\% vs. $24 \%$ ) and convective therapy (73\% vs. $59 \%)$ in the group achieving all targets, the differences did not reach statistical significance $(p=0.247$ and $p=0.259$, respectively). There were no differences in the use of phosphate binders or the dialysis dose. A multivariate analysis found that the use of a $3.0 \mathrm{mEq} / \mathrm{L}$ dialysate Ca concentration (OR 5.756; 1.102-30.077; $\mathrm{p}=0.038$ ) and treatment with cinacalcet (OR 12.684; 1.115-144.352; $\mathrm{p}=0.041$ ) were the factors associated with achieving all K/DOQI targets.

\section{Discussion}

In spite of applying the K/DOQI Clinical Practice Guidelines for Bone Metabolism and Disease, achievement of K/DOQI targets reminds difficult. In 2006, coinciding with the availability in daily clinical practice of paricalcitol and cinacalcet, our HD Unit implemented a new treatment protocol for controlling the bone metabolism parameters better. As Figures 1, 2 and 3 show, this protocol consisted of three practical treatment algorithms, based on the use of cinacalcet and paricalcitol and the individualization of the dialysate $\mathrm{Ca}$ concentration employed, as the main strategies for hyperparathyroidism control, and of dialysis adequacy and combined therapy with sevelamer and Ca acetate for controlling $\mathrm{Ca}$ and $\mathrm{P}$ levels. Although other algorithms for controlling bone metabolism parameters have been developed (Cannata \& Drueke, 2000; Messa et al, 2008; Torregrosa et al., 2011), this, we believe, is the first one to take into account both the drug treatment and HD features, such as the length of dialysis session or the dialysate $\mathrm{Ca}$ concentration recommended.

Application of this new treatment protocol was effective and resulted in significant reductions in mean $\mathrm{Ca}_{\mathrm{Alb}}$, $\mathrm{CaxP}$ and PTH levels (Table 2), with a higher proportion of patients achieving the recommended goals. Noteworthy is the $60.5 \%$ of patients with all four K-DOQI parameters within target ranges in the second year after implementing the protocol (Figure 5). This improvement in K/DOQI targets maintained over time could have a direct impact in the survival of patients, given that the simultaneous control of all bone and mineral metabolisms have been showed to be associated with improved survival (Danese et al., 2008).

Implementation of the protocol entailed the administration of paricalcitol and cinacalcet, a preferential use of convective therapies, and the most widely used dialysate Ca concentration of $3.0 \mathrm{mEq} / \mathrm{L}$ (Tables 4 and 5). However, it is not easy to assess which of the measures carried out, following implementation of the protocol, has the greatest effect on improving the K/DOQI targets observed, given the multiple factors involved in PTH secretion and in $\mathrm{Ca}$ and $\mathrm{P}$ levels. We, therefore, compared the characteristics of the patients who achieved all K/DOQI target ranges during the second year of study and those who did not (Table 5). Although there was higher HD dose and a higher proportion of patients under paricalcitol treatment and convective therapy in the group within all the targets, a multivariate analysis showed that the use of a $3.0 \mathrm{mEq} / \mathrm{L}$ dialysate Ca concentration and the treatment with cinacalcet were the only two factors significantly associated with achievement of all K/DOQI targets.

These findings are consistent with the literature. Cinacalcet, the first calcimimetic available in daily clinical practice, has proven effective for lowering $\mathrm{PTH}, \mathrm{Ca}, \mathrm{P}$ and CaxP 
levels in HD patients (Block et al, 2004; Goodman et al., 2002; Lindberg et al., 2005; Quarles et al., 2003). This ability to lower PTH, while limiting the risks of hyperphosphatemia or hypercalcemia, has improved the achievement of the proposed treatment goals (Block et al., 2008; Messa et al., 2008; Moe et al., 2005), allowing it to be used synergistically in combination with vitamin D sterols (Chertow et al., 2006; Messa et al., 2008). Our protocol took this favourable and complementary effect of combined treatment into account: $60 \%$ of the patients who were on paricalcitol treatment and achieved all K/DOQI goals during the second year of study, also received treatment with cinacalcet. In conclusion, we cannot explain the great improvement in K/DOQI goals achieved throughout the study without the use of cinacalcet, either alone or in association with paricalcitol. It's to note the absence of significant association between the use of paricalcitol and achievement of control of all K/DOQI targets. We think it might be related to the fact that $43 \%$ of the patients were previously treated with calcitriol. Hence it's difficult to detect any advantages in improving bone metabolism parameters with the use of paricalcitol. Despite these results, we still recommend the preferential use of paricalcitol over calcitriol, given the benefits observed in other studies with the selective vitamin D receptor activation (Llach et al., 2001; Sprague et al.,2001; Teng et al., 2003).

Greater use of a $3.0 \mathrm{mEq} / \mathrm{L}$ dialysate Ca concentration was the other factor significantly associated with achieving all K/DOQI targets ( $85 \%$ of patients within all targets). Although optimal dialysate Ca concentration for HD patients has been set at $2.5 \mathrm{mEq} / \mathrm{L}$ according to K-DOQI guidelines, this recommendation is opinion-based and could negatively affect secondary hyperparathyroidism (Argilés et al., 1998; Fernández, et al., 1995). Several studies have reported better control of secondary hyperparathyroidism, without risk of severe hypercalcemia, after raising the dialysate Ca concentration from 2.5 to $3.0 \mathrm{mEq} / \mathrm{L}$ (Argilés, 1995; Malberti \& Raviani, 2004; Molina et al., 2008). A Ca concentration of $3.0 \mathrm{mEq} / \mathrm{L}$ has, therefore, been suggested as the first choice for the majority of patients on HD (Cannata \& Drueke, 2000; Torregrosa et al, 2011; Touissant et al., 2006). In any case, the best approach would be to individualize the prescription of dialysate Ca concentration, as the K-DOQI guidelines noted.

Noteworthy is the absence of significant changes observed in the use of phosphate binders, with the exception of aluminium hydroxide, the use of which was significantly reduced, as evidence of better control of bone metabolism parameters. Although the proportion of patients receiving Ca acetate remained unchanged, the mean total dosage of elemental Ca provided showed a tendency to increase $(451 \pm 151$ vs $562 \pm 275 \mathrm{mg} /$ day; $\mathrm{p}=0.079$ ). The lack of statistical significance could be due to the limited number of patients. This raise in $\mathrm{Ca}$ provided by Ca-containing phosphate binders has been previously reported in another study with cinacalcet therapy (Block et al., 2008), where excessively high doses of Ca provided by binders were necessary in order to avoid hypocalcemia. In our study, however, the mean total dosage of elemental Ca provided remained below the maximum dose recommended by K/DOQI guidelines. We speculate that the relatively small average dose of cinacalcet used $(45.0 \pm 34.6 \mathrm{mg} /$ day), the preferential use of a dialysate Ca concentration of $3.0 \mathrm{mEq} / \mathrm{L}$ and the administration of paricalcitol could explain the absence of the need for excessively high doses of Ca acetate. Finally, we should emphasize the desirability of only using Ca acetate, as the Ca- 
containing phosphate binder, in order to limit the total dosage of elemental Ca provided.

The current study has several limitations. This was an intervention study without a control group. It would have been interesting to study additional markers of bone metabolism such as bone mass, skeletal fracture rates, cardiovascular calcification or arterial function, given that they could provide more valuable information on the overall assessment of renal bone disease than K-DOQI core measurement standard biomarkers. Other limitations of our study were the limited number of patients, which is common in a single-centre study. However, this was compensated for by the long follow-up period and the relatively high number of blood samples analyzed.

\section{Conclusion}

Two years after its implementation, the proposed treatment protocol for control bone metabolism parameters has greatly increased the achievement of K/DOQI treatment targets in most of the HD patients. The protocol entailed the administration of cinacalcet, the replacement of calcitriol by paricalcitol, and the incorporation of individual dialysate $\mathrm{Ca}$ concentration prescriptions into the algorithm, with a preferential use of a dialysate $\mathrm{Ca}$ concentration of $3.0 \mathrm{mEq} / \mathrm{L}$.

\section{Acknowledgment}

The authors express their gratitude to George Mattingley, Jacqueline Clarke, Sam Landete and Arantxa Caño for their collaboration in translating this text. The authors also thank Francisco Maduell, MD, for his assistance in the development of the manuscript.

\section{References}

Al Aly Z, González EA, Martin KJ \& Gellens ME. (2004). Achieving K/DOQI Laboratory Target Values for Bone and Mineral Metabolism: An Uphill Battle. Am J Nephrol, Vol.24, No.4, (August 2004), pp. 422-426. ISSN 0250-8095

Arenas MD, Alvarez U de F, Gil MT, Soriano A, Egea JJ, Millán I, Amoedo ML, Muray S \& Carretón MA. (2006). Application of NKF-K/DOQI Clinical Practice Guidelines for Bone Metabolism and Disease: changes of clinical practices and their effects on outcomes and quality standards in three haemodialysis units. Nephrol Dial Transplant, Vol.21, No.6, (June 2006), pp. 1663-1668. ISSN 0931-0509

Argilés A. (1995). Points to remember when selecting dialysate calcium concentration. Nephrol Dial Transplant, Vol.10, No.4, (April 1995), pp. 451-454. ISSN 0931-0509

Argilés A, Mourad G. (1998). How do we have to use the calcium in the dialysate to optimize the management of secondary hyperparathyroidism? Nephrol Dial Transplant, Vol.13, Suppl.3, (April 1998), pp. S62-S64. ISSN 0931-0509

Block GA, Hulbert-Shearon TE, Levin NW \& Port FK. (1998). Association of serum phosphorus and calcium $\mathrm{x}$ phosphate product with mortality risk in chronic hemodialysis patients: A national study. Am J Kidney Dis, Vol.31, No.4, (April 1998), pp. 607-617. ISSN 0272-6386 
Block GA, Port FK. (2000). Re-evaluation of risks associated with hyperphosphatemia and hyperparathyroidism in dialysis patients: Recommendations for a change in management. Am J Kidney Dis, Vol.35, No.6, (June 2000), pp. 1226-1237. ISSN 02726386

Block GA, Martin KJ, de Francisco ALM, Turner SA, Avram MM, Suranyi MG, Hercz G, Cunningham J, Abu-Alfa AK, Messa P, Coyne DW, Locatelli F, Cohen RM, Evenepoel P, Moe SM, Fournier A, Braun J, McCary LC, Zani VJ, Olson KA, Drüeke TB \&Goodman WG. (2004). Cinacalcet for secondary hyperparathyroidism in patients receiving hemodialysis. N Engl J Med, Vol.350, No.5, (April 2004), pp. 1516-1525. ISSN 0028-4793

Block GA, Klassen PS, Lazarus JM, Ofsthun N, Lowrie EG \& Chertow GM. (2004). Mineral metabolism, mortality, and morbidity in maintenance hemodialysis. J Am Soc Nephrol, Vol.15, No.8, (August 2004), pp. 2208-2218. ISSN 1046-6673

Block GA, Zeig S, Sugihara J, Chertow GM, Chi EM, Turner SA \& Bushinsky DA. (2008). Combined therapy with cinacalcet and low dose of vitamin $\mathrm{D}$ sterols in patients with moderate to severe secondary hyperparathyroidism. Nephrol Dial Transplant, Vol.23, No.7, (July 2008), pp. 2311-2138. ISSN 0931-0509

Cannata JB \& Drueke TB. (2000). Clinical algorithms on renal osteodystrophy. Nephrol Dial Transplant, Vol.15, Suppl.5, (October 2000), pp. S39-S57. ISSN 0931-0509

Chertow GM, Blumenthal S, Turner S, Roppolo M, Stern L, Chi EM \& Reed J. (2006). Cinacalcet hydrochloride (Sensipar) in hemodialysis patients on active vitamin D derivates with controlled PTH and elevated calcium x phosphate. Clin J Am Soc Nephrol, Vol.1, No.2, (March 2006), pp. 305-312. ISSN 1555-9041

Danese MD, Belozeroff V, Smirnakis K \& Rothman KJ. (2008). Consistent control of mineral and bone disorder in incident hemodialysis patients. Clin J Am Soc Nephrol, Vol.3, No.5, (September 2008), pp. 1423-1429. ISSN 1555-9041

Fernández E, Borràs M, Pals B \& Montoliu J. (1995). Low-Calcium Dialysate Stimulates Parathormone Secretion and its Long-Term Use Worsens Secondary Hyperparathyroidism. J Am Soc Nephrol, Vol.6, No.1, (July 1995), pp. 132-135. ISSN 1046-6673

Ganesh SK, Stack AG, Levin NW, Hulbert -Shearon T \& Port FK. (2001). Association of elevated serum $\mathrm{PO} 4, \mathrm{CaxPO} 4$ product, and parathyroid hormone with cardiac mortality risk in chronic hemodialysis patients. J Am Soc Nephrol, Vol.12, No.10, (October 2001), pp. 2131-2138. ISSN 1046-6673

Goodman WG. (2001). Recent developments in the management of secondary hyperparathyroidism. Kidney Int, Vol.59, No.3, (March 2001), pp. 1187-1201. ISSN 0085-2538

Goodman WG, Hladik GA, Turner SA, Blaisdell PW, Goodkin DA, Liu W, Barri YM, Cohen RM \& Coburn JW. (2002). The calcimimetic agent AMG 073 lowers plasma parathyroid hormone levels in hemodialysis patients with secondary hyperparathyroidism. J Am Soc Nephrol, Vol.13, No.4, (April 2002), pp. 1017-1024. ISSN 1046-6673 
Jindal K, Chan CT, Deziel C, Hirsch D, Soroka SD, Tonelli M \& Culleton BF. (2006). Clinical Practice Guidelines for the Canadian Society of Nephrology: Mineral Metabolism. J Am Soc Nephrol, Vol.17, No.3, Suppl.1, (March 2006), pp. S1-S27. ISSN 10466673

Johnson CA, McCarthy J, Bailie GR, Deane J \& Smith S. (2002). Analysis of renal bone disease treatment in dialysis patients. Am J Kidney Dis, Vol.39, No.6, (June 2002), pp. 1270-1277. ISSN 0272-6386

Lindberg JS, Culleton B, Wong G, Borah MF, Clark RV, Shapiro WB, Roger SD, Husserl FE, Klassen PS, Guo MD, Albizem MB \& Coburn JW. (2005). Cinacalcet $\mathrm{HCl}$, an oral calcimimetic agent for the treatment of secondary hyperparthyoridism in hemodialysis and peritoneal dialysis: A randomized double-blind, multicenter study. J Am Soc Nephrol, Vol.16, No.6, (March 2005), pp. 800-807. ISSN 10466673

Llach F\& Yudd M. (2001). Paricalcitol in dialysis patients with calcitriol-resistant secondary hyperparathyroidism. Am J Kidney Dis, Vol.38, No.5 (Suppl 5), (November 2001), pp. S45-S50. ISSN 0272-6386

London GM, Guerin AP, Marchais SJ, Metivier F, Pannier B \& Adda H (2003). Arterial media calcification in end-stage renal disease: Impact on all-cause and cardiovascular mortality. Nephrol Dial Transplant, Vol.18, No.9, (September 2003), pp. 1731-1740. ISSN 0931-0509

Lorenzo V, Martín-Malo A, Pérez-García R, Torregrosa JV, Vega N, de Francisco AL \& Cases A. (2006). Prevalence, clinical correlates and therapy cost of mineral abnormalities among haemodialysis patients: a cross-sectional multicentre study. Nephrol Dial Transplant, Vol.21, No.2, (February 2006), pp. 459-465. ISSN 0931-0509

Maduell F, Górriz JL, Pallardó LM, Pons R \& Santiago C. (2005). Assessment of phosphorus and calcium metabolism and its clinical management in hemodialysis patients in the community of Valencia. J Nephrol, Vol.18, No.6, (December 2005), pp. 739-748. ISSN 1121-8428

Malberti F \& Ravani P. (2004). The choice of the dialysate calcium concentration in the management of patients on haemodialysis and heamodiafiltration. Nephrol Dial Transplant, Vol.18, Suppl.7, (August 2004), pp. S37-S40. ISSN 09310509

Martin KJ \& Gonzalez EA. (2001). Vitamin D analogues for the management of secondary hyperparathyroidism. Am J Kidney Dis, Vol.38, No.5 (Suppl 5), (November 2001), pp. S34-S40. ISSN 0272-6386

Messa P, Macário F, Yaqoob M, Bouman K, Braun J, von Albertini B, Brink H, Maduell F, Graf H, Frazão JM, Bos WJ, Torregrosa V, Saha H, Reichel H, Wilkie M, Zani VJ, Molemans B, Carter D \& Locatelli F. (2008). The OPTIMA study: assessing a new cinacalcet (Sensipar/Mimpara) treatment algorithm for secondary hyperparathyroidism. Clin J Am Soc Nephrol, Vol.3, No.1, (January 2008), pp. 36-45. ISSN 1555-9041 
Moe S \& Drueke TB. (2003). Management of secondary hyperparathyroidism: The importance and the callenge of controlling parathyroid hormone levels without elevating calcium, phosphorous and calcium-phosphorous product. Am J Nephrol, Vol.23, No.6, (November 2003), pp. 369-379. ISSN 0250-8095

Moe SM, Chertow GM \& Coburn JW. (2005). Achieving NKF-K/DOQI bone metabolism and treatment goals with cinacalcet $\mathrm{HCl}$. Kidney Int, Vol.67, No.2, (February 2005), pp. 760-771. ISSN 0085-2538

Moe SM, Drüeke TB, Block GA, Cannata-Andía JB, Elder GJ, Fukagawa M, Jorgetti V, Ketteler M, Langman CB, Levin A, MacLeod AM, McCann L, McCullough PA, Ott SM, Wang AY, Weisinger JR, Wheeler DC, Persson R, Earley A, Moorthi R \& Uhlig K. (2009). KDIGO clinical practice guideline for the diagnosis, evaluation, prevention, and treatment of Chronic Kidney Disease-Mineral and Bone Disorder (CKD-MBD).Kidney Disease: Improving Global Outcomes (KDIGO) CKD-MBD Work Group. Kidney Int, Vol.76, Suppl.113, (August 2009), pp. S1-S130. ISSN 00852538

Molina P, Sánchez P, Garrigós E \& Peris A. (2008). Marked improvement in bone metabolism parameters after raising the dialysate calcium concentration from 2.5 to $3 \mathrm{mEq} / \mathrm{L}$ in non-hypercalcemic hemodialysis patients. Hemodial Int, Vol.12, No.1, (January 2008), pp. 73-79. ISSN 1492-7535

National Kidney Foundation-Kidney Disease Outcomes and Quality Initiative. (2003). K/DOQI Clinical Practice Guidelines for Bone Metabolism and Disease in Chronic Kidney Disease. Am J Kidney Dis, Vol.42, Suppl.3, (October 2003), pp. S1-S201. ISSN 0272-6386

Quarles LD, Sherrard DJ, Adler S, Rosansky SJ, McCary LC, Liu W, Turner SA \& Bushinsky DA. (2003). The calcimimetic AMG 073 as a potential treatment for secondary hyperparathyroidism of end-stage renal disease. J Am Soc Nephrol, Vol.14, No.3, (March 2003), pp. 575-583. ISSN 1046-6673

Slatopolsky E, Weerts C, Lopez-Hilker S, Norwood K, Zink M, Windus D \& Delmez J. (1986). Calcium carbonate as a phosphate binder in patients with chronic renal failure undergoing dialysis. $N$ Eng J Med, Vol.315, No.3, (July 1986), pp. 157-161. ISSN 0028-4793

Sprague SM, Lerma E, McCormmick D, Abraham M \& Battle D. (2001). Suppression of parathyroid hormone secretion in hemodialysis patients: comparison of paricalcitol with calcitriol. Am J Kidney Dis, Vol.38, No.5 (Suppl 5), (November 2001), pp. S51S56. ISSN 0272-6386

Teng M, Wolf M, Lowrie E, Ofsthun N, Lazarus JM \& Thadhani R. (2003). Survival of patients undergoing hemodialysis with paricalctiol or calcitriol therapy. $N$ Engl J Med, Vol.349, No.5, (July 2003), pp. 446-456. ISSN 0028-4793

Torregrosa JV, Bover J, Cannata J, Lorenzo V, de Francisco ALM, Martínez I, Rodríguez M, Arenas L, González E, Caravaca F, Martín-Malo A, Fernández E \& Torres A. (2011). Spanish Society of Nephrology recommendations for controlling mineral and bone disorders in chronic kidney disease patients (S.E.N.-M.B.D.) Nefrologia, Vol.31, Suppl.1, (March 2011), pp. S3-S32. ISSN 0211-6995 
Toussaint N, Cooney P \& Kerr PG. (2006). Review of dialysate calcium concentration in hemodialysis. Hemodial Int, Vol.10, No.4, (October 2006), pp. 326-337. ISSN 14927535 


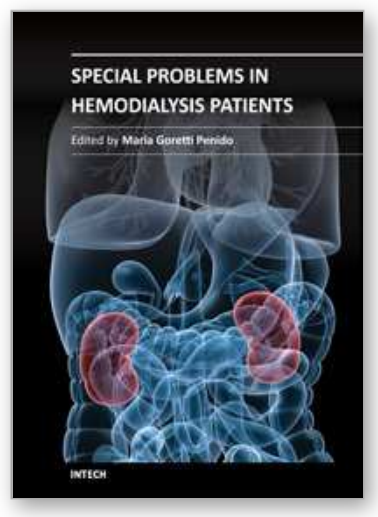

\author{
Special Problems in Hemodialysis Patients \\ Edited by Prof. Maria Goretti Penido
}

ISBN 978-953-307-396-5

Hard cover, 192 pages

Publisher InTech

Published online 14, November, 2011

Published in print edition November, 2011

This book provides an overview of special cases in hemodialysis patients. Authors have contributed their most interesting findings in dealing with patients suffering of other diseases simultaneously, such as diabetes, cardiovascular disease and other health problems. Each chapter has been thoroughly revised and updated so the readers are acquainted with the latest data and observations in these complex cases, where several aspects are to be considered. The book is comprehensive and not limited to a partial discussion of hemodialysis. To accomplish this we are pleased to have been able to summarize state of the art knowledge in each chapter of the book.

\title{
How to reference
}

In order to correctly reference this scholarly work, feel free to copy and paste the following:

Pablo Molina, Pilar Sánchez-Pérez, Ana Peris, José L. Górriz and Luis M. Pallardo (2011). Treatment Protocol for Controlling Bone Metabolism Parameters in Hemodialysis Patients, Special Problems in Hemodialysis Patients, Prof. Maria Goretti Penido (Ed.), ISBN: 978-953-307-396-5, InTech, Available from: http://www.intechopen.com/books/special-problems-in-hemodialysis-patients/treatment-protocol-forcontrolling-bone-metabolism-parameters-in-hemodialysis-patients

\section{INTECH}

open science | open minds

\section{InTech Europe}

University Campus STeP Ri

Slavka Krautzeka 83/A

51000 Rijeka, Croatia

Phone: +385 (51) 770447

Fax: +385 (51) 686166

www.intechopen.com

\section{InTech China}

Unit 405, Office Block, Hotel Equatorial Shanghai

No.65, Yan An Road (West), Shanghai, 200040, China

中国上海市延安西路65号上海国际贵都大饭店办公楼 405 单元

Phone: +86-21-62489820

Fax: +86-21-62489821 
(C) 2011 The Author(s). Licensee IntechOpen. This is an open access article distributed under the terms of the Creative Commons Attribution 3.0 License, which permits unrestricted use, distribution, and reproduction in any medium, provided the original work is properly cited. 